\title{
The Northern Circumpolar Soil Carbon Database: spatially distributed datasets of soil coverage and soil carbon storage in the northern permafrost regions
}

\author{
G. Hugelius $^{1}$, C. Tarnocai ${ }^{2}$, G. Broll ${ }^{3}$, J. G. Canadell ${ }^{4}$, P. Kuhry ${ }^{1}$, and D. K. Swanson ${ }^{5}$ \\ ${ }^{1}$ Department of Physical Geography and Quaternary Geology, Stockholm University, 10691 Stockholm, \\ Sweden \\ ${ }^{2}$ Research Branch, Agriculture and Agri-Food Canada, 960 Carling Ave., Ottawa, Ontario K1A0C6, Canada \\ ${ }^{3}$ Institute of Geography, University of Osnabrück, 49069 Osnabrück, Germany \\ ${ }^{4}$ Global Carbon Project, CSIRO Marine and Atmospheric Research, GPO Box 3023, Canberra, ACT 2601, \\ Australia \\ ${ }^{5}$ National Park Service, Fairbanks Administrative Center, 4175 Geist Road, Fairbanks, Alaska 99709, USA
}

Correspondence to: G. Hugelius (gustaf.hugelius@ natgeo.su.se)

Received: 7 June 2012 - Published in Earth Syst. Sci. Data Discuss.: 13 August 2012
Revised: 13 December 2012 - Accepted: 18 December 2012 - Published: 15 January 2013

\begin{abstract}
High-latitude terrestrial ecosystems are key components in the global carbon (C) cycle. Estimates of global soil organic carbon (SOC), however, do not include updated estimates of SOC storage in permafrostaffected soils or representation of the unique pedogenic processes that affect these soils. The Northern Circumpolar Soil Carbon Database (NCSCD) was developed to quantify the SOC stocks in the circumpolar permafrost region $\left(18.7 \times 10^{6} \mathrm{~km}^{2}\right)$. The NCSCD is a polygon-based digital database compiled from harmonized regional soil classification maps in which data on soil order coverage have been linked to pedon data $(n=1778)$ from the northern permafrost regions to calculate SOC content and mass. In addition, new gridded datasets at different spatial resolutions have been generated to facilitate research applications using the NCSCD (standard raster formats for use in geographic information systems and Network Common Data Form files common for applications in numerical models). This paper describes the compilation of the NCSCD spatial framework, the soil sampling and soil analytical procedures used to derive SOC content in pedons from North America and Eurasia and the formatting of the digital files that are available online. The potential applications and limitations of the NCSCD in spatial analyses are also discussed.
\end{abstract}

The database has the doi:10.5879/ecds/00000001. An open access data portal with all the described GISdatasets is available online at: http://www.bbcc.su.se/data/ncscd/.

\section{Introduction}

High-latitude terrestrial ecosystems are key components in the global carbon (C) cycle (McGuire et al., 2009), and soils in northern permafrost regions store large amounts of soil organic carbon (SOC) (Schuur et al., 2008). Permafrost is a thermal condition in which ground (soil or rock, including ice and organic material) remains at or below $0{ }^{\circ} \mathrm{C}$ for at least two consecutive years (van Everdingen, 1998). Permafrost underlies approximately $24 \%$ of the exposed land surface of the Northern Hemisphere (Zhang et al., 1999). Low temperatures and water logging in permafrost terrain reduces decomposition rates, which has led to the accumulation of large stocks of SOC in mineral permafrost soils and organic soils (Davidson and Janssens, 2006).

The major soil classification systems have some differences in their classification of cold region soils. The US Soil Taxonomy (Soil Survey Staff, 1999; used in this study) and 
the Canadian System of Soil Classification (Soil Classification Working Group, 1998) consider the presence of permafrost as a first order classification criterion and group all permafrost soils as Gelisols or Cryosols, respectively, while unfrozen organic soils are grouped as Histosols. The World reference base for soil resources (IUSS Working Group WRB, 2007) considers the presence of thick organic horizons as a first order classification criterion and groups all organic soils as Histosols (with the added prefix cryic if they are permafrost soils). Permafrost is the second order classification criterion, and mineral permafrost soils are classified as Cryosols.

Perennially frozen mineral and organic soils are important Earth system C pools because of their vulnerability to climate change. This vulnerability results from the remobilization of $\mathrm{C}$ through permafrost thaw and changed surface hydrological conditions (Gruber et al., 2004). If widespread permafrost thaw occurs, large pools of soil organic matter (SOM) that were previously protected from decomposition may become available for biological decomposition leading to increased greenhouse gas fluxes to the atmosphere from northern environments (Khvorostyanov et al., 2008; Schuur et al., 2009; Koven et al., 2011; Schaefer et al., 2011).

Most global SOC estimates converge around 1500$1600 \mathrm{Pg} \mathrm{C}$ for the top meter of the soil, with an additional $500-900 \mathrm{Pg} \mathrm{C}$ stored in the second meter (Eswaran et al., 1993; Batjes, 1996; Jobbagy and Jackson, 2000; Amundson, 2001; Hiederer and Köchy, 2011). However, many global estimates of SOC do not account for pedogenic processes unique to permafrost environments (Tarnocai and Broll, 2008) and the recently updated Harmonised World Soil Database (FAO/IIASA/ISRIC/ISS-CAS/JRC, 2012) does not include a separate classification of permafrost soils. Further, the number of pedons available to describe soils of high-latitude/altitude areas is limited. For example, the combined tundra and alpine ecosystems of the world $(\approx 8-$ $8.8 \times 10^{6} \mathrm{~km}^{2}$ ) are represented by 21,48 and 51 sites in the studies by Schlesinger (1977), Post et al. (1982) and Jobbagy and Jackson (2000), respectively.

The Northern Circumpolar Soil Carbon Database (NCSCD; Tarnocai et al., 2007) was compiled to address this lack of knowledge of the role of permafrost-affected soils in the global C cycle. The NCSCD links 1778 pedons from the northern permafrost regions to several digitized regional/national soil maps to produce a combined circumpolar coverage. Together these datasets have been used to quantify SOC storage in the topsoil $(0-30 \mathrm{~cm}$ depth) and down to a depth of $1 \mathrm{~m}$. Using this database, Tarnocai et al. (2009) estimated SOC mass (SOCM) in the northern permafrost region to be $191 \mathrm{Pg}$ for the topsoil and $496 \mathrm{Pg}$ for the upper meter of soil. Based on limited field data, Tarnocai et al. (2009) estimated SOCM to the $3 \mathrm{~m}$ soil depth to be $1024 \mathrm{Pg}$, of which Gelisols contribute $818 \mathrm{Pg}$ and Histosols $93 \mathrm{Pg}$. With larger uncertainty, the SOCM in deeper deposits $(>3 \mathrm{~m})$ is estimated to be $407 \mathrm{Pg}$ for Pleistocene loess deposits (Yedoma deposits) and 241 Pg for deltaic deposits. Altogether, the total estimated SOCM is $1672 \mathrm{Pg}$, of which $1466 \mathrm{Pg}$ are stored in perennially frozen ground. Based on this study and others, the review by McGuire et al. (2009) provides an estimated range of 1400-1850 Pg C for the combined arctic SOC pool in mineral soils, peatlands, deep alluvial sediments and Yedoma deposits.

Results from these and other studies focusing on SOC storage in permafrost terrain (see also Zimov et al., 2006; Ping et al., 2008a) suggest that estimates of global SOC stocks may underestimate storage in subarctic and arctic ecosystems by a factor of 2 or more. The lower global estimates may be caused by an underestimation of storage in cryoturbated soil horizons (cryoturbation is a process by which organic matter may be transported into deeper soil layers due to repeated freeze-thaw cycles) and organic soils (e.g. see Bockheim, 2007; Tarnocai and Broll, 2008; Ping et al., 2008b; Tarnocai et al., 2009; Hugelius and Kuhry, 2009; Hugelius et al., 2010, 2011). However, comparison between different studies is difficult, as terminology and definitions differ, as do the sizes of the upscaling regions. The northern permafrost regions $\left(18.7 \times 10^{6} \mathrm{~km}^{2}\right.$ of land following Brown et al., 1997) used by Tarnocai et al. (2009) include alpine and tundra ecosystems $\left(\approx 8.8 \times 10^{6} \mathrm{~km}^{2}\right.$ in global estimates), as well as regions of boreal forest in North America and Siberia (boreal forest cover $\approx 12 \times 10^{6} \mathrm{~km}^{2}$ in global estimates). The extent of the northern permafrost regions also includes discontinuous permafrost zones, where the majority of the landscape may actually be permafrost-free.

This paper describes the creation of the NCSCD database as a polygon GIS dataset derived from different regional soil maps from around the circumpolar permafrost region (Fig. 1). It also describes a new set of gridded datasets that have been derived from the original polygon-based database to facilitate use of the NCSCD in further research (available as TIFF files and Network Common Data Form files NetCDF). We also briefly discuss possibilities and potential limitations to the applications of these open access databases in research.

\section{Materials and methods}

\subsection{Sampling and analyses of soils}

The soil map data used for the NCSCD were obtained from different regions/countries (Table 1) using a variety of methods over several decades. Efforts were made to harmonize the data; however, some discrepancies still remain.

\subsubsection{Soil sampling}

North American section: at each site a representative pedon (a three-dimensional body of soil) was investigated by digging soil pits measuring ca. $1 \mathrm{~m} \times 2 \mathrm{~m}$ in area and up to $2 \mathrm{~m}$ in depth. The soil sampling and soil description methods 


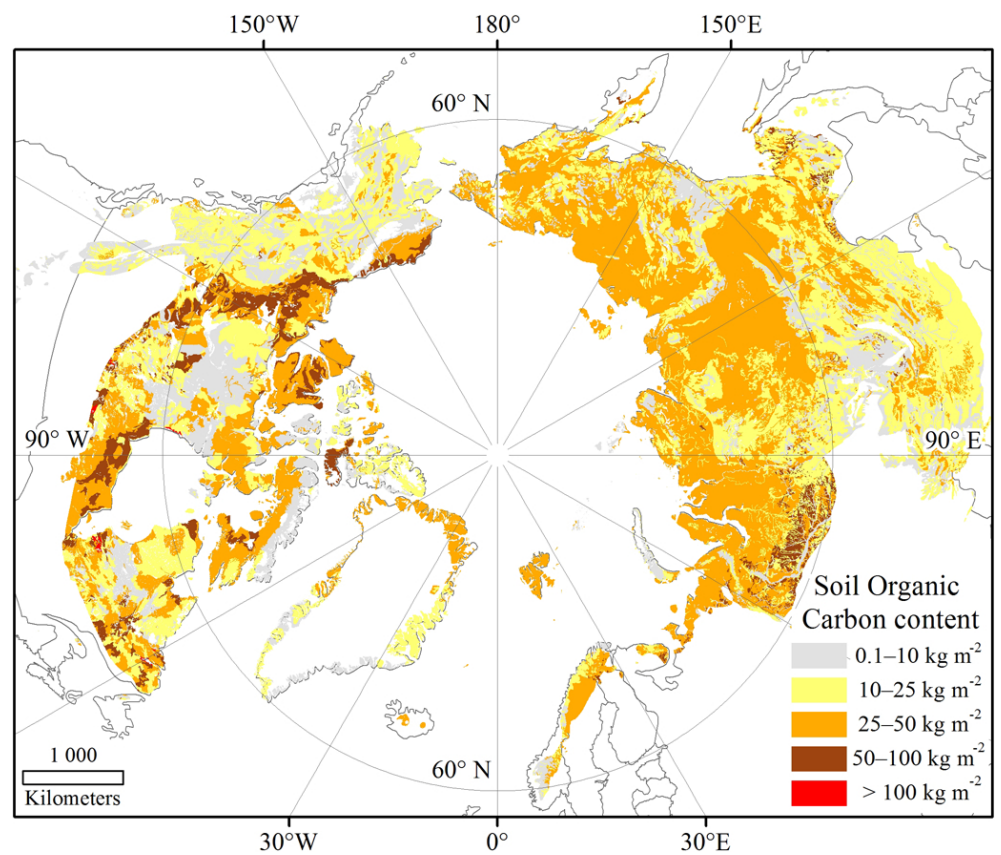

Figure 1. Map showing the spatial extent of the NCSCD and the estimated SOCC to a depth of 1 m. Layout adapted from Tarnocai et al. (2007). Projection North Pole azimuthal equidistant (datum: WGS 84).

Table 1. Data sources for the soil maps constituting the spatial base of the NCSCD.

\begin{tabular}{|c|c|c|c|}
\hline Country or region & Scale & Soil map type & Reference \\
\hline $\mathrm{USA}^{1}$ & $1: 250000$ & Digital & Soil Survey Staff (1997) \\
\hline Canada & $1: 1000000$ & Digital & Tarnocai and Lacelle (1996) \\
\hline Russia & $1: 2500000$ & Printed & Fridland (1988); Naumov (1993) \\
\hline Kazakhstan & $1: 2500000$ & Printed & Uspanov (1976) \\
\hline Mongolia & $1: 3000000$ & Printed & Dorzhgotov and Nogina (1990) \\
\hline Greenland & $1: 7500000$ & Printed & Jakobsen and Eiby (1997) \\
\hline Scandinavia $^{2}$ & $1: 1000000$ & Digital & European Soil Bureau (1999) \\
\hline Iceland & $1: 1500000$ & Printed & Arnalds and Gretarsson (2001) \\
\hline
\end{tabular}

${ }^{1}$ Includes Alaska and the lower contiguous USA. ${ }^{2}$ Includes Svalbard.

for the North American pedons were carried out in accordance with the Expert Committee on Soil Survey (1983) and Soil Survey Staff (1993). Exceptions were made for cryoturbated permafrost-affected mineral soils (Fig. 2). These soils are commonly associated with patterned ground and contain distorted and/or discontinuous horizons. By definition, the pedon includes a whole cycle of the patterned ground (Soil Classification Working Group, 1998). For all pedons, a cross section of at least $1 \mathrm{~m}^{2}$ was excavated. Excavation of the permafrost section of the pedon was carried out using either a gasoline-driven power hammer or the CRREL (Cold Regions Research and Engineering Laboratory) corer (also called SIPRE - Snow, Ice, and Permafrost Research Establishment corer) (Tarnocai, 1993). In cryoturbated permafrostaffected mineral soils, the active layer was generally 50 to $70 \mathrm{~cm}$ deep, but excavation extended to more than the $1 \mathrm{~m}$ depth in order to include the upper permafrost layers, which store considerable amounts of organic C. Perennially frozen organic soils (Fig. 3) were sampled with either the CRREL corer or a chain saw that was able to cut out blocks of frozen peat and expose the soil profile (Tarnocai, 1993). Unfrozen organic soils were sampled using a fixed volume peat auger (known as Russian Peat Corer or minimized Macauley peat auger, Sheppard et al., 1993).

Eurasian section: the sampling method used in the Eurasian part of the NCSCD region was similar to that described above for the active layer of permafrost soils and for unfrozen organic soils. The permafrost layer was sampled by hammering a steel pipe into the frozen soil in $5 \mathrm{~cm}$ increments and retrieving frozen cores in between hammering. This type of coring leads to a displacement of soil material into the core due to the relatively thick wall of the pipe 


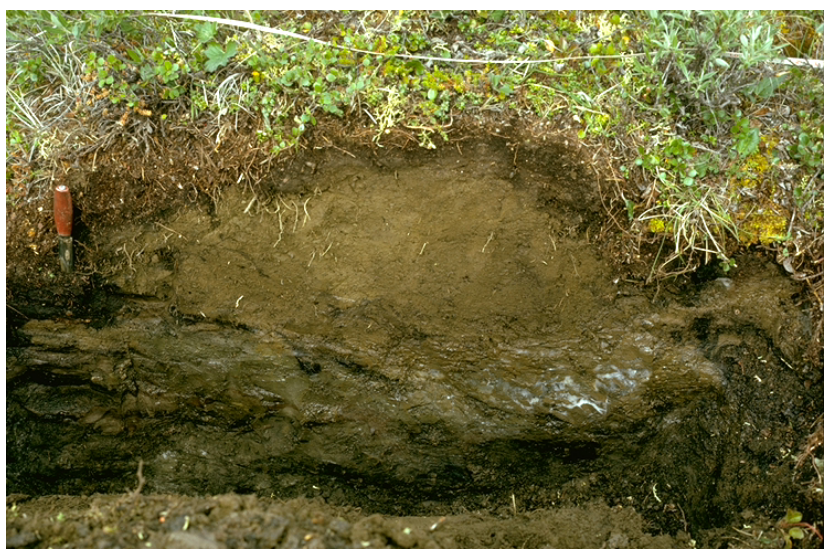

Figure 2. Example of strongly cryoturbated, perennially frozen, mineral soil (Turbel). This soil is associated with the earth hummock type of patterned ground. It contains large concentrations of cryoturbated organic materials (the black areas) in the subsoil and has a high ice content. Photograph by C. Tarnocai, previously published in Jones et al. (2010) and Tarnocai and Bockheim (2011).

(resulting in soil cores that are longer than the actual depth of coring). This displacement of frozen soil material should be taken into consideration when calculating the sample volume; in hard, frozen soils the outer diameter of the pipe should be used for calculating sample volume. Careful measurements of the volume of intact frozen samples or coring into a frozen substance of known bulk density (e.g. massive ground ice) provides an opportunity to calibrate the volume estimates.

\subsubsection{Analytical methods}

Carbon concentration: for the North American pedons, the soil organic carbon concentration (\%OC) was determined by using either the Walkley-Black method or the LECO$\mathrm{CHN}$ analyzer (after treating mineral soil samples with $\mathrm{HCl}$ to remove inorganic carbon). The \% OC data generated by the Walkley-Black method are associated primarily with the older samples (analysed prior to 1980), but a majority of the North American samples were analysed using the LECO analyser (Carter, 1993 and Soil Survey Staff, 1996).

A variety of methods have been used to determine the $\% \mathrm{OC}$ for Eurasian pedons. Some of the \%OC was determined using the Tyrian (1965) method while others were compatible with the Walkley-Black method (Kogut and Frid, 1993) or the wet acid-dichromate digestion method (Arinushlina, 1970). More recently, OC\% was determined using elemental analysers (Kuhry et al., 2002). For mineral horizons in which carbon content had been determined by wet acid-dichromate digestion, the coefficient 1.28 was used to convert data to dry digestion (Kogut and Frid, 1993). For organic horizons, except those in which carbon content had been determined by wet acid-chromium oxide digestion (Ar-

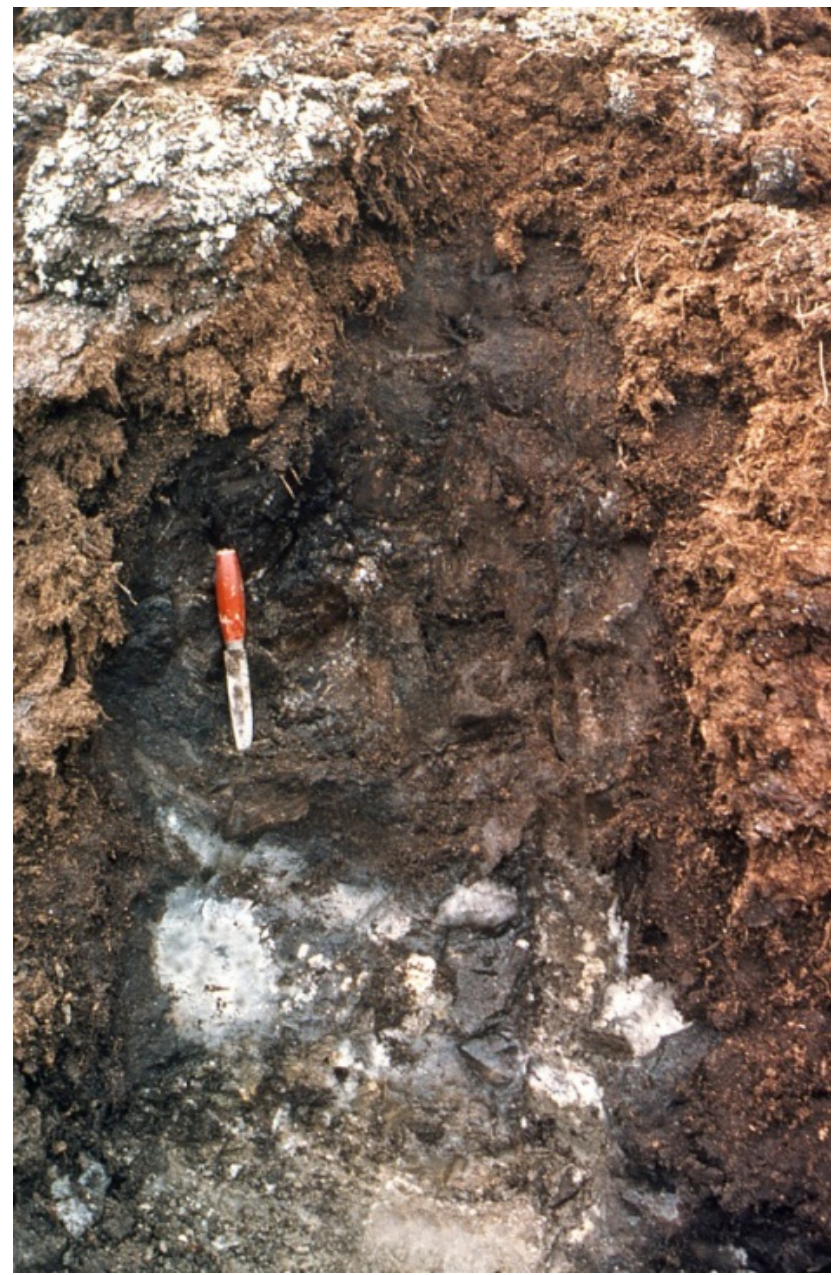

Figure 3. Example of perennially frozen organic soil (Histel) developed on moss peat with a high ice content (white areas) in the subsoil. Photograph by C. Tarnocai, previously published in Jones et al. (2010) and Tarnocai and Bockheim (2011).

inushlina, 1970; Kogut and Frid, 1993) or using elemental analysers, the carbon content was calculated from loss on ignition (Dean, 1974) using the coefficient 0.57 (Botch et al., 1995).

Bulk density: bulk density (BD) for mineral and organic soils was determined by the core sampling method or by the clod method (Culley, 1993). Relatively undisturbed core samples were collected by using a thin metal cylinder pressed into the soil, or by using a fixed volume peat auger, or by using the CRREL sampling tool. In cases where a thicker steel pipe was used (permafrost coring in the Russian pedons), a correction factor was used to compensate for soil displacement from the wall of the pipe when calculating the volume of the core (see Sect. 2.1.1 above). The cores were generally $4-5 \mathrm{~cm}$ in diameter and $5-7 \mathrm{~cm}$ in length. Soils were oven dried to determine dry weights. For the Canadian sector, mineral soil samples were oven dried at $105^{\circ} \mathrm{C}$ (Carter, 1993) and organic soil samples at $55^{\circ} \mathrm{C}$ for 2 to 3 days (McFarlane, 
1969). In the US sector all samples were dried at $110^{\circ} \mathrm{C}$ for 12 to $16 \mathrm{~h}$ (Soil Survey Staff, 1996). For the Eurasian sector, samples collected from the late 1990 s were dried at $95^{\circ} \mathrm{C}$ for $24 \mathrm{~h}$ (Kuhry et al., 2002), but details regarding drying temperatures are unfortunately not available for older samples. Sample volume was determined either through fixed volume field sampling or through the clod method, which uses undisturbed saran-coated clods to maintain shape and volume (Soil Survey Staff, 1996). BD was not determined in many routine analyses, so values had to be determined using pedotransfer functions or rules (Bouma and Van Lanen, 1987). Other commonly used methods were as follows: (1) mean $\mathrm{BD}$ was computed for each profile and this BD was used for soil horizons with missing BD data, or (2) mean BD was determined for each textural class (sand, silt and clay) and substituted for all horizons with missing BD data. For some Russian pedons (Usa River basin, European Russian Arctic), missing BD data were approximated from a relationship between organic carbon content and $\mathrm{BD}$ in the range of bulk densities from 0.40 to $1.80 \mathrm{~g} \mathrm{~cm}^{-3}\left(R^{2}=0.83\right.$; Kuhry et al., 2002). For O-horizons of mineral soil taxa (i.e. all soil taxa except Histosols and the Histel suborder of Gelisols) where BD data were missing, a mean bulk density value of 0.135 was adopted (Botch et al., 1995).

Coarse fragments and ice content: the percent distribution of coarse fragments ( $>2 \mathrm{~mm}$ size) was estimated during the sampling or determined by using the sieve method. Gravimetric ice content was either estimated or determined by using core samples.

\subsection{Soil maps as the spatial database of the NCSCD}

The original NCSCD (Tarnocai et al., 2007) consists of 10 regional polygon files (ESRI Arc/INFO shape files). The spatial data covers permafrost-affected areas in Alaska, Canada, contiguous USA (Conus), Europe, Greenland, Iceland, Kazakhstan, Mongolia, Russia and Svalbard. The regional or national soil maps that form the base of the NCSCD were compiled for geographic scales ranging from $1: 250000$ to 1:7500 000 (Table 1), and the NCSCD was not intended to be presented at a scale larger than 1:1000000.

Most of the data for North America and Europe are available in digital form in local soil databases that have been compiled from existing soil survey maps (Table 1). For remote areas in North America, where less detailed survey maps are available, data from other sources, such as pedon, climate and vegetation data, together with Landsat TM satellite imagery, were used to delineate polygons.

Spatial soil information for Russia, Greenland, Iceland, Kazakhstan, and Mongolia was available only as hard copy maps, which had to be digitized (Table 1). During this process, especially in the case of the Russian maps, the map symbols and classification terms had to be translated into English and the soil classification terms had to be converted to the US Soil Taxonomy (Soil Survey Staff, 1999). Spe- cial meetings of the Cryosol Working Group (International Permafrost Association and IUSS) were held in Europe and North America from 1998 to 2003 to harmonize the data and to ensure that no information loss occurred during translation and data conversion.

\subsection{Calculating SOC stocks}

The NCSCD provides the spatial framework and the data needed to determine the organic carbon stocks in the soils of the permafrost region. The NCSCD contains many thousands of polygons $(>78000)$, with each polygon containing one or more named soils or soil taxa that form the basis for determining the carbon stocks. Representative pedons for each soil taxa (in Eurasia and Greenland; total number of pedons: 609) or named soils (in Canada and United States; total number of pedons: 1169) were selected. These pedons contain all the data needed to calculate soil carbon content (see Eq. 1). The data for the layers that compose each soil (Canada and United States) were entered into the database and were used to calculate the carbon content of each named soil in the polygon while data from pedons of each soil taxa (Eurasia and Greenland) were used to calculate their carbon contents, which were then entered into the database.

The soil organic carbon content (SOCC, $\mathrm{kg} \mathrm{m}^{-2}$ ) was calculated for each of the named soil (Canada and United States) and for the representative pedons for each soil taxa (Eurasia and Greenland) using the formula:

$\mathrm{SOCC}=\mathrm{C} \times \mathrm{BD} \times T \times(1-\mathrm{CF})$

where $\mathrm{C}=$ organic carbon $(\%$ weight $), \mathrm{BD}=$ bulk density $\left(\mathrm{g} \mathrm{cm}^{-3}\right), T=$ depth of soil layer/horizon and $\mathrm{CF}=$ coarse fragments and/or segregated ice content (\% weight). The SOCC data from all sampled soil layers/horizons in each pedon are summed up for the two reference depths $(0-30 \mathrm{~cm}$ and $0-100 \mathrm{~cm}$ ). Mean SOCC for the different named soils or soil taxa are then stored in the database to be used for further calculations or to generate carbon content maps.

SOCM was then determined by multiplying the SOCC of the specific soil by the area of each such soil component in the polygon. These data provide information on the SOCM of each soil in each permafrost zone in the northern circumpolar region and for the production of SOCM maps. The areal and SOCC/SOCM attributes were calculated by projecting each region into an Azimuthal equal area projection relevant to that region. Note that the published dataset described in this paper does not include SOC data from the individual pedons, only the derived calculations of SOCC and SOCM.

\subsection{Description of the NCSCD GIS-polygon files}

All GIS analyses have been performed using the software package ArcGIS 10.0 (ESRI, 2011). Separate polygon files (ESRI ArcMap shape-files) are available for the regions 
Alaska, Canada, contiguous USA (Conusus), Europe, Greenland, Iceland, Kazakhstan, Mongolia, Russia, Scandinavia and Svalbard. The spatial coverage is limited to polygons that either intersect the extent of permafrost terrain described by Brown et al. (2002) or with $>0 \%$ of Gelisol mapped in the polygon.

Each shape-file is connected to a database (polygon attribute table) that contains data on coverage of different soil types, coverage of non-soil areas as well as calculated SOCM and SOCC for each mapped polygon. See Table 2 for detailed information on the data contained in the polygon attribute tables.

In the Russian sector, soil map data were missing for some permafrost-affected land areas (five polygons, total area $39425 \mathrm{~km}^{2}$, missing sections identified through overlay with map of Brown et al., 2002). In these regions, the missing polygons are subdivided according to permafrost zonation (following Brown et al., 2002) and mean values from the corresponding permafrost zones within the Russian sector are reported as a means of data gap-filling (gap-filled polygons are identified by the code -999 in the data field Extent; see Table 2).

In addition to the separate regional files, a merged polygon shape-file covering the whole circumpolar permafrost region is also available. This file contains all polygons from the separate regions and the full associated data, with the exception of the separate regional ID fields and ESRI identifiers.

The polygon vector files are available in geographic latitude/longitude format (World Geodetic System; datum: WGS84) or projected in the North Pole Lambert Azimuthal Equal Area Projection (Datum: WGS84, Units: meters, Longitude of Centre of Projection: $=0^{\circ} 0^{\prime} 0.00^{\prime \prime}$, Latitude of Centre of Projection: $90^{\circ} 0^{\prime} 0.00^{\prime \prime}$, False Easting: 0.0, False Northing: 0.0).

\subsection{New gridded NCSCD datasets of SOC storage and soil coverage}

To facilitate use of the NCSCD for applications requiring gridded GIS-data, selected parts of the data stored in the polygon shape-files have been converted to a common georeferenced gridded format (also called raster files, based on a rectangular grid of pixels that store one data value in each pixel; file format used is TIFF-files), which can be read by most desktop GIS-applications and to the Network Common Data Form format (NetCDF-files). As with the polygon files, the gridded files are available for the separate permafrostaffected regions and for the whole circumpolar permafrost region.

The following variables were converted into gridded data: SOCC $0-30 \mathrm{~cm}$ depth, SOCC $0-100 \mathrm{~cm}$ depth, and percent coverage of Turbels (cryoturbated permafrost soils), Histels (organic permafrost soils), Orthels (non-cryoturbated permafrost-affected mineral soils), Histosols (organic soils without permafrost), other soils (all mineral soils without permafrost), and non-soil areas (see Table 3 for more detailed description of the gridded variables). Each variable is stored in a separate gridded file; to describe the full soil/non-soil coverage in any pixel, all five grids describing coverage are needed.

To avoid storing floating-point numbers in the gridded datasets (floating point rasters have larger file sizes) while still maintaining a precision equivalent to one significant decimal of a $\mathrm{kgC}$, the unit hectogram (hg) $\mathrm{C} \mathrm{m}^{-2}$ was used for the SOCC grids (divide number by ten to get $\mathrm{kg} \mathrm{C} \mathrm{m}^{-2}$ ). For the circumpolar region there are also grids showing the extent of the permafrost region. To derive some rasters, information from several different polygon attribute table columns was combined.

To minimize errors along polygon edges, initial rasterization was done with a pixel resolution of $100 \mathrm{~m}$. Pixels that stretched across the border of several polygons are assigned the mean value of the affected polygons. The highresolution (100 $\mathrm{m}$ grid-size) rasters were subsequently resampled (using bilinear interpolation) to coarser resolution: 0.012 degree ( 0.012 degrees longitude are equivalent to $1 \mathrm{~km}$ at $\approx 42.5$ degrees latitude, which is the southernmost extent of the NCSCD) or $1 \mathrm{~km}$ pixel size for regional datasets and $0.05,0.1,0.25,0.5$ and 1 degree pixel resolution for circumpolar datasets. Datasets are available in geographic latitude/longitude format (World Geodetic System; datum: WGS84) or projected in the Lambert Azimuthal Equal Area Projection. All rasterization and resampling was done using the TIFF data format in the North Pole Lambert Azimuthal Equal Area Projection. In the final stages of data processing, files were projected to WGS84 and converted to NetCDFformat.

\section{Discussion}

The NCSCD is a scientific resource that can be utilized to determine stocks of SOC in the northern circumpolar permafrost region and to explore carbon-climate feedbacks resulting from its vulnerability to climate change. The spatial base of the NCSCD is polygon shape files originally derived from regional soil maps, with a new addition of gridded products to facilitate research applications using such data (TIFFfiles and NetCDF-files).

If possible, we recommend researchers to base analyses on the separate regional datasets rather than merged circumpolar datasets. This is because the spatial soil maps for the separate regions were developed at different times with different methods and at different spatial scales. Before using the NCSCD, refer to the information in Table 1 and consider the given references and scale of regional soil maps for guidance. The NCSCD was compiled at scales intended for analyses at circumpolar or large regional scales, and, therefore, NCSCD applications need to be correspondingly consistent with that and caution needs to be taken when the database 
Table 2. Description of the data contained in the polygon attribute tables of NCSCD. The table gives a description of the data, the column field name, the precision of numeric fields (Prec), the data format the variable is stored in (Form: $\mathrm{F}=$ float numeric field, $\mathrm{I}=$ integer numeric field, $\mathrm{S}=$ string) and the number of decimal values of float numeric fields (Dec).

\begin{tabular}{|c|c|c|c|c|}
\hline Description & Field name & Prec & Form & Dec \\
\hline Area of Polygon $\left(\mathrm{m}^{2}\right)$ & AREA & 14 & $\mathrm{~F}$ & 3 \\
\hline Perimeter $(\mathrm{m})$ & PERIMETER & 14 & $\mathrm{~F}$ & 3 \\
\hline Internal ESRI \# & Varies & 5 & I & - \\
\hline Internal ESRI ID & Varies & 5 & I & - \\
\hline Link to original source ${ }^{1}$ & Varies & 5 & I & - \\
\hline Gelisol \% of polygon & GELISOL_PCT & 3 & I & - \\
\hline Histosol $\%$ of polygon & HISTOSOL_PCT & 3 & I & - \\
\hline Mollisol \% of polygon & MOLLISOL_PCT & 3 & I & - \\
\hline Vertisol $\%$ of polygon & VERTISOL_PCT & 3 & I & - \\
\hline Aridisol $\%$ of polygon & ARIDISOL_PCT & 3 & I & - \\
\hline Andisol $\%$ of polygon & ANDISOL_PCT & 3 & I & - \\
\hline Entisol \% of polygon & ENTISOL_PCT & 3 & I & - \\
\hline Ultisol \% of polygon & ULTISOL_PCT & 3 & I & - \\
\hline Spodosol $\%$ of polygon & SPODOSOL_PCT & 3 & I & - \\
\hline Inceptisol $\%$ of polygon & INCEPTISOL_PCT & 3 & I & - \\
\hline Alfisol $\%$ of polygon & ALFISOL_PCT & 3 & I & - \\
\hline Natric soils \% of polygon & NATRIC_PCT & 3 & I & - \\
\hline Aqu soils \% of polygon & AQU_PCT & 3 & I & - \\
\hline Water $\%$ of polygon & WATER_PCT & 3 & I & - \\
\hline Rockland \% of polygon & ROCKLAND_PCT & 3 & I & - \\
\hline Glacier $\%$ of polygon & GLACIER_PCT & 3 & I & - \\
\hline Miscellaneous $\%$ of polygon & MISC_PCT & 3 & I & - \\
\hline Gelisol-Turbel $\%$ of polygon & TURBEL_PCT & 3 & I & - \\
\hline Gelisol-Orthel $\%$ of polygon & ORTHEL_PCT & 3 & I & - \\
\hline Gelisol-Histel \% of polygon & HISTEL_PCT & 3 & I & - \\
\hline Total & TOTAL_PCT & 3 & I & - \\
\hline Permafrost extent ${ }^{2}$ & EXTENT & 4 & $\mathrm{~S}$ & - \\
\hline Gelisol area $\left(\mathrm{m}^{2}\right)$ & GE_AREA & 16 & $\mathrm{~F}$ & 1 \\
\hline Alfisol area $\left(\mathrm{m}^{2}\right)$ & AL_AREA & 16 & $\mathrm{~F}$ & 1 \\
\hline Entisol area $\left(\mathrm{m}^{2}\right)$ & EN_AREA & 16 & $\mathrm{~F}$ & 1 \\
\hline Inceptisol area $\left(\mathrm{m}^{2}\right)$ & IN_AREA & 16 & $\mathrm{~F}$ & 1 \\
\hline Spodosol area $\left(\mathrm{m}^{2}\right)$ & SP_AREA & 16 & $\mathrm{~F}$ & 1 \\
\hline Natric soils area $\left(\mathrm{m}^{2}\right)$ & NA_AREA & 16 & $\mathrm{~F}$ & 1 \\
\hline Aqu soil area $\left(\mathrm{m}^{2}\right)$ & AQ_AREA & 16 & $\mathrm{~F}$ & 1 \\
\hline Vertisol area $\left(\mathrm{m}^{2}\right)$ & VE_AREA & 16 & $\mathrm{~F}$ & 1 \\
\hline Mollisol area $\left(\mathrm{m}^{2}\right)$ & MO_AREA & 16 & $\mathrm{~F}$ & 1 \\
\hline Histosol area $\left(\mathrm{m}^{2}\right)$ & HI_AREA & 16 & $\mathrm{~F}$ & 1 \\
\hline Aridisol area $\left(\mathrm{m}^{2}\right)$ & AR_AREA & 16 & $\mathrm{~F}$ & 1 \\
\hline Andisol area $\left(\mathrm{m}^{2}\right)$ & AN_AREA & 16 & $\mathrm{~F}$ & 1 \\
\hline Ultisol area $\left(\mathrm{m}^{2}\right)$ & UL_AREA & 16 & $\mathrm{~F}$ & 1 \\
\hline Turbel area $\left(\mathrm{m}^{2}\right)$ & GET_AREA & 16 & $\mathrm{~F}$ & 1 \\
\hline Orthel area $\left(\mathrm{m}^{2}\right)$ & GEO_AREA & 16 & $\mathrm{~F}$ & 1 \\
\hline Histel area $\left(\mathrm{m}^{2}\right)$ & GEH_AREA & 16 & $\mathrm{~F}$ & 1 \\
\hline Rockland area $\left(\mathrm{m}^{2}\right)$ & ROCK_AREA & 16 & $\mathrm{~F}$ & 1 \\
\hline Glacier area $\left(\mathrm{m}^{2}\right)$ & GLACIER_AREA & 16 & $\mathrm{~F}$ & 1 \\
\hline Miscellaneous area $\left(\mathrm{m}^{2}\right)$ & MISC_AREA & 16 & $\mathrm{~F}$ & 1 \\
\hline SOCM $30 \mathrm{~cm}$ depth Gelisol (kg) & GE_30SOCM & 16 & $\mathrm{~F}$ & 1 \\
\hline SOCM $30 \mathrm{~cm}$ depth Alfisol (kg) & AL_30SOCM & 16 & $\mathrm{~F}$ & 1 \\
\hline SOCM $30 \mathrm{~cm}$ depth Entisol (kg) & EN_30SOCM & 16 & $\mathrm{~F}$ & 1 \\
\hline SOCM $30 \mathrm{~cm}$ depth Inceptisol (kg) & IN_30SOCM & 16 & $\mathrm{~F}$ & 1 \\
\hline SOCM $30 \mathrm{~cm}$ depth Spodosol (kg) & SP_30SOCM & 16 & $\mathrm{~F}$ & 1 \\
\hline SOCM $30 \mathrm{~cm}$ depth Natric $(\mathrm{kg})$ & NA_30SOCM & 16 & $\mathrm{~F}$ & 1 \\
\hline SOCM $30 \mathrm{~cm}$ depth Aqu soils (kg) & AQ_30SOCM & 16 & $\mathrm{~F}$ & 1 \\
\hline
\end{tabular}


Table 2. Continued.

\begin{tabular}{lllll}
\hline Description & Field name & Prec & Form & Dec \\
\hline SOCM $30 \mathrm{~cm}$ depth Vertisol $(\mathrm{kg})$ & VE_30SOCM & 16 & $\mathrm{~F}$ & 1 \\
SOCM $30 \mathrm{~cm}$ depth Mollisol $(\mathrm{kg})$ & MO_30SOCM & 16 & $\mathrm{~F}$ & 1 \\
SOCM $30 \mathrm{~cm}$ depth Histosol $(\mathrm{kg})$ & HI_30SOCM & 16 & $\mathrm{~F}$ & 1 \\
SOCM $30 \mathrm{~cm}$ depth Aridisol $(\mathrm{kg})$ & AR_30SOCM & 16 & $\mathrm{~F}$ & 1 \\
SOCM $30 \mathrm{~cm}$ depth Andisol $(\mathrm{kg})$ & AN_30SOCM & 16 & $\mathrm{~F}$ & 1 \\
SOCM $30 \mathrm{~cm}$ depth Ultisol $(\mathrm{kg})$ & UL_30SOCM & 16 & $\mathrm{~F}$ & 1 \\
SOCM $30 \mathrm{~cm}$ depth Turbel $(\mathrm{kg})$ & GET_30SOCM & 16 & $\mathrm{~F}$ & 1 \\
SOCM $30 \mathrm{~cm}$ depth Orthel $(\mathrm{kg})$ & GEO_30SOCM & 16 & $\mathrm{~F}$ & 1 \\
SOCM $30 \mathrm{~cm}$ depth Histel $(\mathrm{kg})$ & GEH_30SOCM & 16 & $\mathrm{~F}$ & 1 \\
SOCM $100 \mathrm{~cm}$ depth Gelisol $(\mathrm{kg})$ & GE_100SOCM & 16 & $\mathrm{~F}$ & 1 \\
SOCM $100 \mathrm{~cm}$ depth Alfisol $(\mathrm{kg})$ & AL_100SOCM & 16 & $\mathrm{~F}$ & 1 \\
SOCM $100 \mathrm{~cm}$ depth Entisol $(\mathrm{kg})$ & EN_100SOCM & 16 & $\mathrm{~F}$ & 1 \\
SOCM $100 \mathrm{~cm}$ depth Inceptisol $(\mathrm{kg})$ & IN_100SOCM & 16 & $\mathrm{~F}$ & 1 \\
SOCM $100 \mathrm{~cm}$ depth Spodosol $(\mathrm{kg})$ & SP_100SOCM & 16 & $\mathrm{~F}$ & 1 \\
SOCM $100 \mathrm{~cm}$ depth Natric $(\mathrm{kg})$ & NA_100SOCM & 16 & $\mathrm{~F}$ & 1 \\
SOCM $100 \mathrm{~cm}$ depth Aqu $(\mathrm{kg})$ & AQ_100SOCM & 16 & $\mathrm{~F}$ & 1 \\
SOCM $100 \mathrm{~cm}$ depth Vertisol $(\mathrm{kg})$ & VE_100SOCM & 16 & $\mathrm{~F}$ & 1 \\
SOCM $100 \mathrm{~cm}$ depth Mollisol $(\mathrm{kg})$ & MO_100SOCM & 16 & $\mathrm{~F}$ & 1 \\
SOCM $100 \mathrm{~cm}$ depth Histosol $(\mathrm{kg})$ & HI_100SOCM & 16 & $\mathrm{~F}$ & 1 \\
SOCM $100 \mathrm{~cm}$ depth Aridisol $(\mathrm{kg})$ & AR_100SOCM & 16 & $\mathrm{~F}$ & 1 \\
SOCM $100 \mathrm{~cm}$ depth Andisol $(\mathrm{kg})$ & AN_10OSOCM & 16 & $\mathrm{~F}$ & 1 \\
SOCM $100 \mathrm{~cm}$ depth Ultisol $(\mathrm{kg})$ & UL_100SOCM & 16 & $\mathrm{~F}$ & 1 \\
SOCM $100 \mathrm{~cm}$ depth Turbel $(\mathrm{kg})$ & GET_100SOCM & 16 & $\mathrm{~F}$ & 1 \\
SOCM $100 \mathrm{~cm}$ depth Orthel $(\mathrm{kg})$ & GEO_10OSOCM & 16 & $\mathrm{~F}$ & 1 \\
SOCM $100 \mathrm{~cm}$ depth Histel $(\mathrm{kg})$ & GEH_100SOCM & 16 & $\mathrm{~F}$ & 1 \\
SOCC $30 \mathrm{~cm}$ depth polygon $\left(\mathrm{kg} \mathrm{m}{ }^{-2}\right)$ & SOCC_30CM & 8 & $\mathrm{~F}$ & 1 \\
SOCC $100 \mathrm{~cm}$ depth polygon $\left(\mathrm{kg} \mathrm{m}{ }^{-2}\right)$ & SOCC_100CM & 8 & $\mathrm{~F}$ & 1 \\
Soil Area $\left(\mathrm{m}^{2}\right.$ ) & SOIL_AREA & 16 & $\mathrm{~F}$ & 1 \\
SOCM $30 \mathrm{~cm}$ depth polygon $(\mathrm{kg})$ & SOCM_30CM & 16 & $\mathrm{~F}$ & 1 \\
SOCM $100 \mathrm{~cm}$ depth polygon $(\mathrm{kg})$ & SOCM_100CM & 16 & $\mathrm{~F}$ & 1 \\
\hline
\end{tabular}

${ }^{1}$ This polygon identification field is only found in the regional polygon datasets, not in the merged

Circumpolar dataset. Also note that the field has different names in different regions

(e.g. SMU/MUID/MAPUNIT_ID etc.); the different field names correspond to the nomenclature used when

digitizing that specific regional soil map.

2 Permafrost extent following Brown et al. (1997): c = continuous permafrost, $d=$ discontinuous permafrost,

$\mathrm{i}=$ isolated permafrost and $\mathrm{s}=$ sporadic permafrost. Those polygons that have empty fields correspond to areas where polygons outside the extent of the Brown et al. (1997) map are described as having $>0 \%$ Gelisol in the regional soil maps. Gap-filled polygons that were missing original data are marked with the code -999.

Table 3. Description of the NCSCD variables that have been converted to gridded file formats (TIFF-files and NetCDF-files). Each variable is stored in a separate gridded file; to describe the full soil/non-soil coverage in any pixel, all five grids describing coverage are needed.

\begin{tabular}{ll}
\hline Variable & Description \\
\hline SOCC 0-30 cm depth & SOCC $\left(\mathrm{hgC} \mathrm{m}^{-2}\right)$ in the 0-30 cm depth interval \\
SOCC $0-100 \mathrm{~cm}$ depth & SOCC $\left(\mathrm{hgC} \mathrm{m}^{-2}\right)$ in the $0-100 \mathrm{~cm}$ depth interval \\
Coverage Turbels & Coverage $(\%)$ of cryoturbated permafrost soils \\
Coverage Histels & Coverage $(\%)$ of organic permafrost soils \\
Coverage Orthels & Coverage $(\%)$ of mineral, non-cryoturbated permafrost soils \\
Coverage Histosols & Coverage $(\%)$ of organic soils (permafrost free) \\
Coverage other soils & Coverage $(\%)$ of all permafrost free mineral soil taxa \\
Coverage non-soil & Coverage $(\%)$ of non-soil areas (i.e. water, rockland, glacier and misc.) \\
Extent of permafrost region & Mask for pixels that fall within the NCSCD permafrost extent \\
\hline
\end{tabular}


is used for local-scale analyses (see Kuhry et al., 2010 for examples and discussion).

Map production always includes a degree of generalization, and maps compiled at small scales will be more generalized. Problems associated with this have been expressed as the modifiable areal unit problem (MAUP) and/or ecological fallacy, both well-known issues in geographical analyses (Openshaw, 1984). The core of MAUP is that geographical analyses of spatially continuous variables impose arbitrary spatial delineations of zones depending on the scale of the analysis. In essence, the soil map polygons of the NCSCD partly reflect the mapping scale and the choices made by scientists/cartographers that made the maps. If the mapping was repeated at a different scale, the results would likely be different. An ecological fallacy occurs when it is inferred that results based on analysis of grouped data (such as a generalized soil map polygon) are valid for individual data points contained within that group or region (Openshaw, 1984). In the context of the NCSCD, this applies to the individual pixel values of the gridded products (TIFF files and NetCDF files). The individual pixels have fixed and relatively high resolution, but the data in them are derived from spatial polygon units of varying resolution and degree of resolution. Therefore, the gridded NCSCD datasets should not be used for local-scale analyses based on a small number of pixels. Individual pixel values should rather be seen as reflecting their immediate spatial domain and the conditions in the surrounding region. There are currently no quantitative measures of the uncertainties/errors associated with using the NCSCD to estimate SOC storage. Tarnocai et al. (2009) assigned different confidence levels (ranging from very low to high) to the different partitions of the circumpolar SOCM estimates. Storage in the $0-1 \mathrm{~m}$ soil depth for the North American sector was ascribed a confidence level of medium to high (66-80\%) while confidence in the data for the Eurasian sector was set at low to medium (33-66\%) because of data scarcity. In a regional study of SOC storage from the western Russian Arctic, Hugelius (2012) demonstrated that the combined uncertainties in landscape SOC estimates introduced by variability in sampled populations and spatial errors in upscaling maps were within $\pm 11 \%$ (at a $95 \%$ confidence level). However, uncertainties depend on the landscape complexity and scale of the study, and studies performed at a circumpolar scale are expected to have considerably higher variability and uncertainty.

While there are limitations to the local-scale application of the NCSCD, the database remains a highly useful scientific asset for spatial analyses covering larger areas. To date, the NCSCD is the only comprehensive dataset dedicated to quantifying the globally significant permafrost $\mathrm{C}$ pool of the northern circumpolar region.

\section{Data access}

The NCSCD is currently hosted by the Bert Bolin Centre for Climate Research at Stockholm University, Sweden. The database has the doi:10.5879/ecds/00000001. An open access data portal with all the described GIS-datasets is available online at: http://www.bbcc.su.se/data/ncscd/.

Acknowledgements. The digitization and translation to English of the individual soil maps was supported by the USDA National Soil Survey Center. All database development, GIS work and data analyses were supported by the Research Branch of Agriculture and Agri-Food Canada. We would also like to thank Chien-Lu Ping, Vladimir Stolbovoi, Sergey Goryachkin and the late Galina Mazhitova for providing some of the North American and Russian pedon data.

The compilation of this manuscript and the online publication of the NCSCD is supported by grants from the Bert Bolin Centre for Climate Research at Stockholm University, the International Permafrost Association, the EU 7th framework PAGE21 project, the Nordic Centres of Excellence DEFROST project and a grant of the Swedish Research Council as a part of the International Program CryoCARB. This effort is also a contribution to the Global Carbon Project of the Earth System Science Partnership, the Carbon Pools in Permafrost regions Project of the International Permafrost Association and the Vulnerability of Permafrost Carbon Research Coordination Network.

Edited by: H.-W. Hubberten

\section{References}

Amundson, A.: The Carbon budget in soils, Annu. Rev. Earth Planet. Sc., 29, 535-62, 2001.

Arnalds, O. and Gretarsson, E.: Generalized Soil Map of Iceland, 2nd Edn., Agric. Res. Inst., Reykjavik, Iceland, 2001.

Arinushkina, E. V.: Manual for Chemical Analysis of Soils, 2nd Edn., Moscow State University, Moscow, 487 pp., 1970 (in Russian).

Bouma, J. and Van Lanen, H. A. J.: Transfer functions and threshold values: from soil characteristics to land qualities, in: Quantified Land Evaluation, edited by: Beek, K. J., Burrough, P. A., and McCormack, D. E., ITC Publication 6, International Institute for Aerospace Survey and Earth Sciences, Enschede, 106-110, 1987.

Batjes, N. H.: Total carbon and nitrogen in the soils of the world, Eur. J. Soil Sci., 47, 151-163, 1996.

Bockheim, J. G.: Importance of cryoturbation in redistributing organic carbon in permafrost-affected soils, Soil Sci. Soc. Am. J., 71, 1335-1342, 2007.

Bohn, H. L.: Estimate of organic carbon in world soils: II, Soil Sci. Soc. Am. J., 46, 1118-1119, 1982.

Botch, M. S., Kobak, K. I., Vinson, T. S., and Kolchugina, T. P.: Carbon pools and accumulation in peatlands of the former Soviet Union, Global Biochem. Cy., 9, 37-46, 1995.

Brown, J., Ferrians Jr., O. J., Heginbottom, J. A., and Melnikov, E. S.: Circum-Arctic map of permafrost and ground-ice conditions, 
1:10 000 000, Map CP-45, United States Geological Survey, International Permafrost Association, 1997.

Brown, J., Ferrians Jr., O. J., Heginbottom, J. A., and Melnikov, E. S.: Circum-Arctic Map of Permafrost and Ground-Ice Conditions, version 2, Boulder, Colorado USA, National Snow and Ice Data Center, 2002.

Carter, M. R. (Ed.): Soil Sampling and Methods of Analysis, Canadian Society of Soil Science, Lewis Publishers, Boca Raton, Florida, 823 pp., 1993.

Culley, J. L. B.: Density and compressibility, in: Soil Sampling and Methods of Analysis, edited by: Carter, M. R., Canadian Society of Soil Science, Lewis Publishers, Boca Raton, Florida, Chapter 71, 529-539, 1993.

Davidson, E. A. and Janssens, I. A.: Temperature sensitivity of soil carbon decomposition and feedbacks to climate change, Nature, 440, 165-173, 2006.

Dean, W. E.: Determination of carbonate and organic matter in calcareous sediments and sedimentary rocks by loss on ignition: Comparison with other methods, J. Sediment. Petrol., 44, 242248, 1974

Dorzhgotov, D. and Nogina, N. A.: Khors (The soil map of Mongolia), in: Bügd Nairamdakh Mongol ArdUls, Undesnii Atlas (National Atlas of the Mongolian People's Republic), edited by: Orshikh, N., Morgunova, N. A., and Rodionov, M. N., 66-67, BNMAU-yn Shinzhlekh Ukhaany Akad., Ulan Bator, 1990 (in Russian).

ESRI: ArcGIS Desktop: Release 10, Environmental Systems Research Institute, Redlands, CA, USA, 2011.

Eswaran, H., Van Den Berg, E., and Reich, P.: Organic carbon in soils of the world, Soil Sci. Soc. Am. J., 57, 192-194, 1993.

European Soil Bureau: The European Soil Database, version 1.0[CD-ROM], Joint Res. Cent., Ispra, Italy, 1999.

Expert Committee on Soil Survey: The Canada Soil Information System (CanSIS), Manual for Describing Soils in the Field, edited by: Day, J. H., Research Branch Agriculture Canada, Ottawa, Ontario, 1983.

FAO/IIASA/ISRIC/ISS-CAS/JRC: Harmonized World Soil Database (version 1.2). FAO, Rome, Italy and IIASA, Laxenburg, Austria, 2012.

Fridland, V. M.: Pochvennaya karta RSFSR (Soil map of theRSFSR), scale 1:2500 000, V. V. Dokuchayev Soils Inst., Admin. for Geod. And Cartogr., Gosagroprom, Moscow, 1988.

Gruber, N., Friedlingstein, P., Field, C. B., Valentini, R., Heimann, M., Richey, J. E., Romero-Lankao, P., Schulze, D., and Chen, C. T. A.: The vulnerability of the carbon cycle in the 21 st century: An assessment of carbon-climate-human interactions, in: The Global Carbon Cycle: Integrating Humans, Climate, and the Natural World, edited by: Field, C. and Raupach, M., Island Press, Washington, DC, 45-76, 2004.

Hiederer, R. and Köchy, M.: Global Soil Organic Carbon Estimates and the Harmonized World Soil Database, EUR 25225 EN, Publications Office of the European Union, 79 pp., 2011.

Hugelius, G.: Spatial upscaling using thematic maps: an analysis of uncertainties in permafrost soil carbon estimates, Global Biogeochem. Cy., 26, GB2026, doi:10.1029/2011GB004154, 2012.

Hugelius, G. and Kuhry, P.: Landscape partitioning and environmental gradient analyses of soil organic carbon in a permafrost environment, Global Biogeochem. Cy., 23, GB3006, doi:10.1029/2008GB003419, 2009.
Hugelius, G., Kuhry, P., Tarnocai, C., and Virtanen, T.: Soil Organic Carbon Pools in a Periglacial Landscape; a Case Study from the Central Canadian Arctic, Permafrost Periglac., 21, 1629, doi:10.1002/ppp.677, 2010.

Hugelius, G., Virtanen T., Kaverin D., Pastukhov A., Rivkin F., Marchenko S., Romanovsky V., and Kuhry P.: High-resolution mapping of ecosystem carbon storage and potential effects of permafrost thaw in periglacial terrain, European Russian Arctic, J. Geophys. Res., 116, G03024, doi:10.1029/2010JG001606, 2011.

IUSS Working Group WRB: World reference base for soil resources 2006: First update 2007, Rep. 103, Food and Agric. Org. of the U.N., Rome, Italy, 2007.

Jakobsen, B. H. and Eiby, A.: A soil map of Greenland, in: 2nd International Conference on Cryopedology, edited by: Zaboeva, I. V., p. 43, Inst. of Biol., Komi Sci. Cent., Russ. Acad. of Sci., Syktyvkar, Russia, 1997.

Jobbagy, E. G. and Jackson, R. B.: The Vertical Distribution of Soil Organic Carbon and Its Relation to Climate and Vegetation, Ecol. Appl., 10, 423-436, 2000.

Jones, A., Stolbovoi, V., Tarnocai, C., Broll, G., Spaargaren, O., and Montanarella, L. (Eds.): Soil Atlas of the Northern Circumpolar Region, European Commision, Publications Office of the European Union, Luxembourg, 144 pp., 2010.

Khvorostyanov, D. V., Ciais, P., Krinner, G., Zimov, S. A., Corradi, C., and Guggenberger, G.: Vulnerability of permafrost carbon to global warming. Part II: sensitivity of permafrost carbon stock to global warming, Tellus B, 60, 265-275, 2008.

Kogut, B. and Frid, A.: Comparative evaluation of methods of determining humus concentration in soils, Pochvovedenie, 9, 119123, 1993 (in Russian).

Koven, C. D., Ringeval, B., Friedlingstein, P., Ciais, P., Cadule, P., Khvorostyanov, D., Krinner, G., and Tarnocai, C.: Permafrost carbon-climate feedbacks accelerate global warming, P. Natl. Acad. Sci. USA, 108, 14769-14774, doi:10.1073/pnas.1103910108, 2011.

Kuhry, P., Mazhitova, G. G., Forest, P.-A., Deneva, S. V., Virtanen, T., and Kultti, S.: Upscaling soil organic carbon estimates for the Usa Basin (Northeast European Russia) using GIS-based landcover and soil classification schemes, Dan. J. Geogr., 102, 11-25, 2002.

Kuhry, P., Dorrepaal, E., Hugelius, G., Schuur, E. A. G., and Tarnocai, C.: Potential remobilization of belowground permafrost carbon under future global warming, Permafrost Periglac., 21, 208-214, doi:10.1002/ppp.684, 2010.

McFarlane, I. C. (Ed.): Muskeg Engineering Handbook, National Research Council of Canada, Associate Committee on Geotechnical Research, Muskeg Subcommittee, University of Toronto Press, Toronto, Canada, 1969.

McGuire, A. D., Anderson, L. G., Christensen, T. R., Dallimore, S., Guo, L., Hayes, D. J., Heimann, M., Lorenson, T. D., Macdonald, R. W., and Roulet, N.: Sensitivity of the carbon cycle in the Arctic to climate change, Ecol. Monogr., 79, 523-555, 2009.

Naumov, E. M.: Soil map of the north-east of Eurasia, scale 1:2 500 000, V. V. Dokuchaev Soil Inst., Moscow, 1993.

Openshaw, S.: The modifiable unit areal problem. Concepts and Techniques in Modern Geography, Vol. 38, Geo Books, Norwich, UK, 1-40, 1984. 
Ping, C. L., Michaelson, G. J., Jorgenson, M. T., Kimble, J. M, Epstein, H., Romanovsky, V. E., and Walker, D. A.: High stocks of soil organic carbon in the North American region, Nat. Geosci., 1, 615-619, 2008a.

Ping, C. L., Michaelson, G. J., Kimble, J. M., Romanovsky, V. E., Shur, Y. L., Swanson, D. K., and Walker, D. A.: Cryogenesis and soil formation along a bioclimate gradient in Arctic North America, J. Geophys. Res., 113, G03S12, doi:10.1029/2008JG000744, 2008b.

Post, W. M., Emmanuel, W. R., Zinke, P. J., and Stangenberger, A. G.: Soil carbon pools and world life zones, Nature, 298, 156-159, 1982.

Schaefer, K., Zhang, T., Bruhwiler, L., and Barrett, A. P.: Amount and timing of permafrost carbon release in response to climate warming, Tellus B, 63, 165-180, 2011.

Schlesinger, W. H.: Carbon balance in terrestrial detritus, Annu. Rev. Ecol. Syst., 8, 51-81, 1977.

Schuur, E. A. G., Bockheim, J., Canadell, J. G., Euskirchen, E., Field, C. B., Goryachkin, S. V, Hagemann, S., Kuhry, P., Lafleur, P. M., Lee, H., Mazhitova, G., Nelson, F. E., Rinke, A., Romanovsky, V. E., Shiklomanov, N., Tarnocai, C., Venevsky, S., Vogel, J. G., and Zimov, S. A.: Vulnerability of Permafrost Carbon to Climate Change: Implications for the Global Carbon Cycle, BioScience, 58, 701-714, doi:10.1641/B580807, 2008.

Schuur, E. A. G., Vogel, J. G., Crummer, K. G., Lee, H., Sickman, J. O., and Osterkamp, T. E.: The effect of permafrost thaw on old carbon release and net carbon exchange from tundra, Nature, 459, 556-559, 2009.

Sheppard, M., Tarnocai, C., and Thibault, D. H.: Sampling organic soils, in: Soil Sampling and Methods of Analysis, edited by: Carter, M. R., Canadian Society of Soil Science, Lewis Publishers, Boca Raton, Florida, Chapter 42, 423-439, 1993.

Soil Classification Working Group: The Canadian System of Soil Classification, Agriculture and Agrifood Canada Publ. 1646 (revised), NRC Research Press, Ottawa, Canada, 187 pp., 1998.

Soil Survey Staff: Soil Survey Manual, US Department of Agriculture, Handbook No. 18, Washington, DC, USA, 437 pp., 1993.

Soil Survey Staff: Soil Survey Laboratory Methods Manual, Soil Survey Investigations Report No. 42, US Department of Agriculture, National Soil Survey Center, Lincoln, NE, 693 pp., 1996.

Soil Survey Staff: The State Soil Geographic Database, STATSGO, USDA-NRCS, National Soil Survey Center, Lincoln, NE, USA, 1997.
Soil Survey Staff: Soil Taxonomy: A Basic System of Soil Classification for Making and Interpreting Soil Surveys, in: Agric. Handb., vol. 436, 2nd Edn, US Dep. of Agric., Washington, DC, USA, 869 pp., 1999.

Tarnocai, C.: Sampling frozen soils, in: Soil Sampling and Methods of Analysis, edited by: Carter, M. R., Canadian Society of Soil Science, Lewis Publishers, Boca Raton, Florida, Chapter 71, 755-765, 1993.

Tarnocai, C. and Bockheim, J. G.: Cryosolic soils of Canada: Genesis, distribution and classification, Can. J. Soil Sci., 91, 749-762, doi:10.4141/CJSS10020, 2011.

Tarnocai, C. and Broll, G.: Soil Organic Carbon Stocks in the Northern Permafrost Region and Their Role in Climate Change, Ninth International Conference on Permafrost, Proceedings, 17511755, 2008.

Tarnocai, C. and Lacelle, B.: Soil organic carbon of Canada map, Eastern Cereal and Oilseed Research Centre, Agriculture and Agri-Food Canada, Research Branch, Ottawa, Ontario, Canada, 1996.

Tarnocai, C., Swanson, D., Kimble, J., and Broll, G.: Northern Circumpolar Soil Carbon Database. Research Branch, Agriculture and Agri-Food Canada, Ottawa, Canada (digital database), 2007.

Tarnocai, C., Canadell, J., Mazhitova, G., Schuur, E. A. G., Kuhry, P., and Zimov, S.: Soil organic carbon stocks in the northern circumpolar permafrost region, Global Biogeochem. Cy., 23, GB2023, doi:10.1029/2008GB003327, 2009.

Tyrin, U. V.: Soil organic matter and its role in the soil fertility, Nauka Publishing House, Moscow, Russia, 319 pp., 1965 (in Russian).

Uspanov, U. U. (Ed.): Pochvennaya karta Kazakhskoy SSR (Soil map of the Kazakh SSR), scale 1:2500 000, Glavnoe Upravlenie Geodezii Kartografii, Moscow, 1976 (in Russian).

van Everdingen, R. (Ed.): Multi-language glossary of permafrost and related ground-ice terms, Boulder, CO: National Snow and Ice Data Center/World Data Center for Glaciology, 1998 (revised May 2005).

Zhang, T., Barry, R. G., Knowles, K., Heginbottom, J. A., and Brown, J.: Statistics and characteristics of permafrost and ground-ice distribution in the Northern Hemisphere, Polar Geography, 23, 132-154, doi:10.1080/10889379909377670, 1999.

Zimov, S. A., Schuur, E. A. G., and Chapin, F. S.: Permafrost and the global carbon budget, Science, 312, 1612-1613, 2006. 